Available online at GSC Online Press Directory

GSC Biological and Pharmaceutical Sciences

e-ISSN: 2581-3250, CODEN (USA): GBPSC2

\title{
Chemical composition of isoflavones compounds and antioxidants from Feijoa sellowiana leaves
}

\author{
Aniq Filali Ouafaa ${ }^{1, *}$, Elfarnini Maryama ${ }^{2}$, Abdel-hamid Abdallah Abakar ${ }^{2}$ and Blaghen Mohamed ${ }^{2,3}$ \\ ${ }^{1}$ Laboratory of Physiopathology, Genetic Molecular and Biotechnology, Faculty of Sciences, Aïn Chock, Hassan II \\ University, Casablanca, Morocco. \\ ${ }^{2}$ Laboratory of Microbiology, Pharmacology, Biotechnology and Environment, Faculty of Sciences, Aïn Chock, Hassan II \\ University, Casablanca, Morocco. \\ ${ }^{3}$ Laboratory of Plant Biotechnology, Ecology and Ecosystem Valorization, Faculty of Sciences, El Jadida, Chouaïb \\ Doukkali University, El Jadida, Morocco.
}

Publication history: Received on 20 August 2019; revised on 13 September 2019; accepted on 21 September 2019

Article DOI: https://doi.org/10.30574/gscbps.2019.9.1.0157

\begin{abstract}
Isoflavonic compounds and antioxidants from the leaves of Feijoa sellowiana Berg grown in Casablanca (Morocco) was analyzed by a sensitive and reliable ultra-fast liquid chromatography tandem mass spectrometry (UFLC-MS/MS) method. The identified compounds were rich in phenolics compounds, thus fifteen constituents were found.
\end{abstract}

Keywords: Feijoa sellowiana; Myrtaceae; Polyphenol compounds; Antioxidants; ESI (Electronspray ionization).

\section{Introduction}

Reactive Oxygen Species (ROS) were produced as a result of oxidative metabolism in the body. They were annihilated by antioxidants, but in case of inversion of the balance in the favor of ROS, they become harmful to organic molecules such as proteins, nucleic acids and lipids. In this case, they present a danger and were at the onset of several diseases such as cardiovascular diseases, cancer, neurodegenerative and diabetic diseases [1,2,3]. Modern life with the high-fat and sugar diet in prepared industrial dishes containing synthetic preservative and taste-correcting additives, as well as sedentary lifestyles, makes men more vulnerable and over time they develop more and more diseases. The diet mode rich in fruits and vegetables allow reducing these ROS and their impact on biomolecules. Indeed, fruits and vegetables contained biomolecules, antioxidant polyphenols that help maintained a balance in favor of antioxidants and help preserve good health. A study for importance intake of vegetable, fruit and legumes was associated with reduced risk of mortality in European diabetic population and decreased cardiovascular diseases [4]. Faced with this recrudescence of diseases, many people were to look for products of natural origin. Plants with their different parts, leaves, stems, buds, roots and fruits were a huge field of research because plants were very rich in polyphenols. Owing to their antioxidant capacity and mainly flavonoids $[5,6]$ and their beneficial implications for human health on different diseases, the interest in using these phenolic compounds in food was increasing. Polyphenols were an important group in plants, vegetables, fruits, cereals and legumes. They were synthesized by plants in response to environmental stresses, whether from pests or other plants or contained in the soil [7]. In recent years a plant native to South America, Feijoa sellowiana (F. sellowiana), has aroused great interest among scientists because of its high content of polyphenols, particularly the flavonoids. Several studies have shown that these flavonoids could attenuate and inhibit cell oxidative stress, responsible for the installation of several diseases, such as cancer, cardiovascular diseases, neurodegenerative diseases, diabetes $[3,8,9]$. F. sellowiana has been shown to have various activities, antibacterial and antioxidant effects $[10,11,12]$, antifungal effects [13], due to its composition rich in antioxidants flavonoids. In a previous study carried

\footnotetext{
${ }^{*}$ Corresponding author

E-mail address: ouafa.aniqfilali@gmail.com
} 
out in our laboratory, leaf and fruit extracts of $F$. sellowiana showed the presence of secondary metabolites such as saponosids, tannins, steroids and terpenes. They have shown antimicrobial activities [12]. F. sellowiana belongs to the Myrtaceae family, native to South America where it adapted to a warm temperate climate. It was introduced in Europe and the Mediterranean basin; Spain, France, Portugal, and Italy around the 19th century [14]. Thereafter, Feijoa plantations were then established in North Africa, and other countries. Actually thanked to its sweet aromatic fruits, it was widely spread through the world for its ease adaptation to the subtropical climate. In some countries such as Australia, the fruit was used in industry as syrup, jam and other products $[15,16]$. The purpose of this study was to investigate the flavonoid and antioxidant compounds in the leaves of the feijoa plant (Acca sellowiana [Berg] Burret, synonym Feijoa sellowiana) found in Morocco and to compare its composition with feijoa from other regions.

\section{Material and methods}

\subsection{Plant material}

Leaves of F. sellowiana Berg (Myrtaceae) were collected in September and November 2017 in Casablanca.

\subsection{Extraction and isolation}

The extraction was carried out by successive exhaustion of plant materials, using water as solvent. $20 \mathrm{~g}$ of $F$. sellowiana leaves were crushed and piled up in a cartridge which was deposited in the Soxhlet device with $250 \mathrm{ml}$ of solvent for each extraction. The temperature of extraction is $100^{\circ} \mathrm{C}$.

Once the extraction was finished, after 16 hours, the solvent were eliminated by evaporation using a rotary evaporator under reduced pressure to avoid any degradation of compounds existing in the extract. Obtained extracts with a volume of $1 \mathrm{ml}$ of water were kept at $4{ }^{\circ} \mathrm{C}$ before analysis. The extract ( $5 \mu \mathrm{l}$ ) was analyzed by a sensitive and reliable ultra fast liquid chromatography tandem mass spectrometry (UFLC-MS/MS) method.

The chromatographic profiles were performed using the BEH-c18 column ( $50 \mathrm{~cm} \times 2.1 \mathrm{~mm} \times 1.7 \mu \mathrm{m})$ with a gradient from 5 to $100 \%$ of B , with solvent A ( $0.1 \%$ formic acid in water) and solvent B $0.1 \%$ formic acid in methanol. The elution was followed at a flow rate of $1 \mathrm{ml} / \mathrm{min}$ and the total time was 15 minutes.

At all times, the profiles were acquired with ESI in negative mode and in Full Scan with a resolution of 70.000. In order to identify we worked with standards, to determine retention times and exact masses. For this reason, we used several solutions containing analytes of different types. This has been analyzed in Trace Finder (analysis software).

The standards have been tested as 100 or $250 \mathrm{ppb}$.

\section{Results and discussion}

Analysis of the leaf extract of $F$. sellowiana revealed that it was rich in flavonoids and antioxidants such as cathequin, daidzin, quercetin, ellagic acid, and gallic acid, salicylic acid, caffeic acid. The chromatographic profiles and composition of the phenolic compounds identified from the leaf extract were shown in figure 1 and table 1.

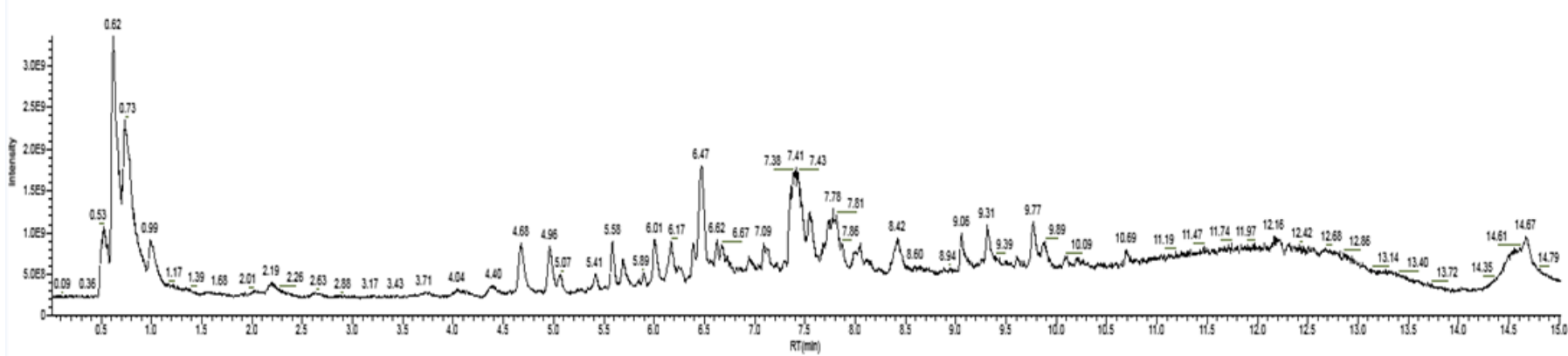

Figure 1 Chromatogram presenting results of UFLC-MS/MS analysis of leaves extract 
Table 1 Results of the phenolic composition of the leaves of F. sellowiana

\begin{tabular}{|c|c|c|c|c|c|c|c|c|c|}
\hline Found & Confirmed & Target Name & $+/-$ & Aire & RT & Formula & $\begin{array}{l}\text { Expected } \\
\mathrm{m} / \mathrm{z}\end{array}$ & $\begin{array}{l}\text { Aire } \\
\text { standard }\end{array}$ & $\begin{array}{l}\text { Concentration } \\
(\mathrm{mg} / \mathrm{kg})\end{array}$ \\
\hline $\mathrm{X}$ & 1 of 1 & Gallic acid & - & $1.84 \mathrm{E}+09$ & 1 & $\mathrm{C}_{7} \mathrm{H}_{6} \mathrm{O}_{5}$ & 169.0143 & 32654111 & 5.635 \\
\hline $\mathrm{X}$ & 1 of 1 & $\begin{array}{l}(+) \text { Gallo } \\
\text { catechin }\end{array}$ & - & 124098446 & 1.55 & $\mathrm{C}_{15} \mathrm{H}_{14} \mathrm{O}_{7}$ & 305.0667 & 28774978 & 0.431 \\
\hline $\mathrm{X}$ & 1 of 1 & $(+)$ Catechin & - & $1.221 \mathrm{E}+09$ & 4.96 & $\mathrm{C}_{15} \mathrm{H}_{14} \mathrm{O}_{6}$ & 289.0718 & 87576711 & 1.4 \\
\hline \multirow[t]{2}{*}{$\mathrm{X}$} & 1 of 1 & Cafeic acid & - & 9727743 & 5.53 & $\mathrm{C}_{9} \mathrm{H}_{8} \mathrm{O}_{4}$ & 179.035 & 69709331 & 0.014 \\
\hline & N/A & $\begin{array}{l}\text { Epigallocatechin } \\
\text { Gallate }\end{array}$ & - & $\mathrm{N} / \mathrm{A}$ & 5.76 & $\mathrm{C}_{22} \mathrm{H}_{18} \mathrm{O}_{11}$ & 457,0776 & & \\
\hline $\mathrm{X}$ & 1 of 1 & (-)Epicatechin & - & $\begin{array}{l}618519160 \\
18989 p p m\end{array}$ & 6 & $\mathrm{C}_{15} \mathrm{H}_{14} \mathrm{O}_{6}$ & 289.0718 & 32590602 & 19 \\
\hline $\mathrm{X}$ & 1 of 1 & Daidzin & - & 3175204 & 6.47 & $\mathrm{C}_{21} \mathrm{H}_{20} \mathrm{O}_{9}$ & 415.1035 & $\begin{array}{l}1012018 \\
100 \mathrm{ppb}\end{array}$ & 0.314 \\
\hline $\mathrm{X}$ & 1 of 1 & $\begin{array}{l}\text { Epicatechin } \\
\text { gallate }\end{array}$ & - & 7614077 & 6.73 & $\mathrm{C}_{22} \mathrm{H}_{18} \mathrm{O}_{10}$ & 441.0827 & 19916303 & 0.380 \\
\hline $\mathrm{X}$ & 1 of 1 & Taxifolin & - & 1416976 & 6.82 & $\mathrm{C}_{15} \mathrm{H}_{12} \mathrm{O}_{7}$ & 303.051 & 20053190 & 0.007 \\
\hline \multirow[t]{2}{*}{$\mathrm{X}$} & 1 of 1 & $\begin{array}{l}\text { Gibberellic acid } \\
\text { GA3 }\end{array}$ & - & 28820474 & 7.05 & $\mathrm{C}_{19} \mathrm{H}_{22} \mathrm{O}_{6}$ & 345.1344 & $\begin{array}{l}53046145 \\
250 \mathrm{ppb}\end{array}$ & 0.14 \\
\hline & N/A & Genistin & - & N/A & 7.08 & $\mathrm{C}_{21} \mathrm{H}_{20} \mathrm{O}_{10}$ & 431.0984 & $\begin{array}{l}4359976 \\
100 \mathrm{ppb}\end{array}$ & \\
\hline $\mathrm{X}$ & 1 of 1 & Ellagic acid & - & $3.643 E+09$ & 7.36 & $\mathrm{C}_{14} \mathrm{H}_{6} \mathrm{O}_{8}$ & 300.999 & 5463159 & 66.7 \\
\hline \multirow[t]{2}{*}{$\mathrm{X}$} & 1 of 1 & Salicilic acid & - & 161547050 & 7.61 & $\mathrm{C}_{7} \mathrm{H}_{6} \mathrm{O}_{3}$ & 137.0244 & 102762290 & 0.4 \\
\hline & $\mathrm{N} / \mathrm{A}$ & Quercetin-Glc & - & N/A & 7.72 & $\mathrm{C}_{21} \mathrm{H}_{20} \mathrm{O}_{12}$ & 463.0882 & 194003749 & \\
\hline \multirow[t]{3}{*}{$\mathrm{X}$} & 1 of 1 & Kaempferol-Glc & - & 363516162 & 7.79 & $\mathrm{C}_{21} \mathrm{H}_{20} \mathrm{O}_{11}$ & 447.0933 & 48805580 & 0.745 \\
\hline & $\mathrm{N} / \mathrm{A}$ & Eriodyctiol & - & N/A & 8.05 & $\mathrm{C}_{15} \mathrm{H}_{12} \mathrm{O}_{6}$ & 287.0561 & 603095417 & \\
\hline & $\mathrm{N} / \mathrm{A}$ & Daidzein & - & N/A & 8.27 & $\mathrm{C}_{15} \mathrm{H}_{10} \mathrm{O}_{4}$ & 253.0506 & 96053502 & \\
\hline $\mathrm{X}$ & 1 of 1 & Quercetin & - & 172099299 & 8.42 & $\mathrm{C}_{15} \mathrm{H}_{10} \mathrm{O}_{7}$ & 301.0354 & 205798683 & 0.084 \\
\hline \multirow[t]{2}{*}{$\mathrm{X}$} & 1 of 1 & Naringenin & - & 1317830 & 8.6 & $\mathrm{C}_{15} \mathrm{H}_{12} \mathrm{O}_{5}$ & 271.0612 & 93839136 & 0.0015 \\
\hline & $\mathrm{N} / \mathrm{A}$ & Genistein & - & N/A & 8.75 & $\mathrm{C}_{15} \mathrm{H}_{10} \mathrm{O}_{5}$ & 269.0456 & 95366988 & \\
\hline \multirow[t]{3}{*}{$\mathrm{X}$} & 1 of 1 & Jasmonic acid & - & 5285094 & 9 & $\mathrm{C}_{12} \mathrm{H}_{18} \mathrm{O}_{3}$ & 209.1183 & 71870317 & 0.018 \\
\hline & $\mathrm{N} / \mathrm{A}$ & Kaempferol & - & $\mathrm{N} / \mathrm{A}$ & 9.01 & $\mathrm{C}_{15} \mathrm{H}_{10} \mathrm{O}_{6}$ & 285.0405 & 195349586 & \\
\hline & $\mathrm{N} / \mathrm{A}$ & Apigenin & - & $\mathrm{N} / \mathrm{A}$ & 9.09 & $\mathrm{C}_{15} \mathrm{H}_{10} \mathrm{O}_{5}$ & 269.0456 & 8787744 & \\
\hline
\end{tabular}

The results of analysis of F. Sellowiana leaf compounds growing in Casablanca-Morocco, showed a richness in flavonoid compounds. We found fifteen compounds in the leaves of $F$. sellowiana as shown in the table 1 , such as flavanols monomeric, catechin, epicatechin, epigalocatechin, galocatechin andtaxifolin, quercetin, ellagic acid, galic acid, salicylic acid and jasmonic acid. Compounds such as quercetin, gallic acid, catechin, flavonoids, daidzin, genistin and others flavonoids daidzein, genistein, prunetin, biochanin, formononetin have been identified in leaf extracts in F. sellowiana and other myrtaceae, Psidium guajava and Psidium littorale Raddi [17]. Poodi et al. [18] found gallic acid, catechin, quercetin, apigenin, rutin and ferulic acid in a leaf ethanol extract. Quercitin, ellagic acid, flavones, isoquecitin, and other flavonoids have been identified in leaves of Feijoa sellowiana [19]. We identified and confirmed 15 polyphenols and their concentrations were estimated using standards. 
The results showed that the concentrations of the various polyphenols identified were relatively low compared to those reported in the literature [19]. For example, we found values of 5.64; $1.4 ; 19 ; 66.7 ; 0.75 ; 0.4 ; 0.018 \mathrm{mg}$ equivalents per kg Gallic acid, (+) Catechin, (-) Epicatechin, Ellagic acid, Kaempferol-Glc, Salicylic acid and Jasmonic acid, respectively (table 1).

Indeed these values were lower than those reported by Aoyama wich found gallic acid at $123 \mathrm{mg} / \mathrm{g}$, quercetin at 41 $\mathrm{mg} / \mathrm{g}$ in an ethanolic leaf extract. The concentrations of these isoflavones were low, perhaps because the plant was grown in a greenhouse. On the other hand, the method of extraction used, soxhlet device, have shown a low yield compared with other technical extraction. In a study on the Soxhlet method of extracting compounds from $F$. sellowiana leaves, showed that the ultrasonic extraction technique combined with pre-leaching allowed a better yield of phenol concentrations Poodi et al. [18]. Other factors influence the polyphenol composition such as environmental conditions, light, soil type, plant maturity stage and genetic factors. These flavonoids found in the leaves of $F$. sellowiana have shown numerous pharmacological activities, activities mediated by antioxidant and therefore anti-inflammatory reactions, inflammation leading to the development of diseases [20].

\section{Conclusion}

Polyphenols, through the consumption of fruits, vegetables, cereals, and plants, prevent the onset of diseases by reducing the formation of free radicals. This preventive aspect of the various diseases is an essential point to preserve good health and to reduce diseases. We were interested in F. sellowiana, a plant of tropical and subtropical regions and could thus adapt to the subtropical climate of Morocco. Although the quantitative results obtained were very low compared to other studies, whereas the presence of most of the flavonoids found in the leaves of $F$. sellowiana was in agreement, which gave reason to hope a better adapted conditions of cultivation of the plant. This shrub constituted a precious source of polyphenols and that the flavonoids could interest the food, cosmetic or pharmaceutical industries and merited more attention for its cultivation in Morocco.

\section{Compliance with ethical standards}

\section{Acknowledgments}

This work was supported by Casablanca Hassan II University fund for laboratory.

\section{Disclosure of conflict of interest}

The authors have declared that no competing interest exists.

\section{References}

[1] Vauzour D, Rodriguez-Mateos A, Corona G, Oruna-Concha MJ and Spencer JPE. (2010). Polyphenols and human health: prevention of disease and mechanisms ofaction. Nutrients, 2, 1106-1131.

[2] Zhou Y, Zheng J, Li, Y, Xu DP, Li S, Chen YM and Li HB, (2016). Natural polyphenols for prevention and treatment of cancer. Nutrients, 8, 515 .

[3] Li AL, Li S, Zhang YJ, Xu XR, Chen YM and Li HB. (2014). Resources and Biological Activities of Natural Polyphenols. Nutrients, 6, 6020-6047.

[4] Noethlings U, Schulze MB, Weikert C, Boeing H, van der Schouw YT, Bamia C, Benetou V, Lagiou P, Krogh V, Beulens JWJ, Peeters PHM, Halkjaer J, Tjonneland A, Tumino R, Panico S, Masala G, Clavel-Chapelon F, de Lauzon B, Boutron-Ruault M-C, Vercambre M-N, Kaaks R, Linseisen J, Overvad K, Arriola L, Ardanaz E, Gonzalez CA, Tormo MJ, Bingham S, Khaw KT, Key TJA, Vineis P, Riboli E, Ferrari P, Boffetta P, Bueno-de-Mesquita HB, van der A DL, Berglund G, Wirfält E, Hallmans G, Johansson I, Lund E, Trichopoulo A. (2008). Intake of Vegetables, Legumes and Fruit and Risk for All-Cause, Cardiovascular, and Cancer Mortality in a European Diabetic Population. Journal of Nutrition, 138, 775-781.

[5] Hanasaki Y, Ogawa S, and Fnkui S, (1994). The correlation between active oxygens scavenging and antioxidative effects of flavonoids. Free Radical Biology and Medicine, 16, 845-850.

[6] Hussain T, Tan B, Yin Y, Blachier F, Tossou MC and Rahu N. (2016). Oxidative Stress and Inflammation: What Polyphenols Can Do for Us? Oxidative Medicine and Cellular Longevity, 2016, 743297. 
[7] Mierziak J, Kostyn K and Kulma A, (2014). Flavonoids as Important Molecules of plant Interactions with the Environment. Molecules, 19, 16240-16265.

[8] Mattera R, Benvenuto M, Giganti MG, Tresoldi I, Pluchinotta FR, Bergante S, Tettamanti G, Masuelli L, Manzari V, Modesti A and Bei R. (2017). Effects of Polyphenols on Oxidative Stress-Mediated Injury in Cardiomyocytes. Nutrients, 9, 523, 1-43.

[9] Umeno A, Horie M, Murotomi K, Nakajima Y and Yoshida Y, (2016). Antioxidative and Antidiabetic Effects of NaturalPolyphenols and Isoflavones. Molecules, 21,708.

[10] Basile A,Vuotto ML, Violante U, Sorbo S, Martone G, Castaldi-Cobianchi R, (1997). Antibactérial activity in Actinidia chinensis, Feijoa sellowiana and Aberia caffra. International Journal of Antimicrobial Agents, 8, 199203.

[11] Beyhan Ö, Elmastaş M and Gedikli F, (2010). Total phenolic compounds and antioxidant capacity of leaf, dry fruit and fresh fruit of feijoa (Acca sellowiana, Myrtaceae). Journal of $\quad$ Medicinal Plants Research, 4, 1065-1072.

[12] Elfarnini M, Abdel-hamid AA, Achir M, Jamaleddine J and Blaghen M, (2018). Antibacterial and antifungal activities of hexane and acetone extracts of sheets and fruits of Feijoa sellowiana 0. GSC Biological and Pharmaceutical Sciences, 03, 035-044.

[13] Vuotto ML, Basile A, Mosccatiello V, De Sole P, Castaldo-Cobianchi R, Laghi E, Ielpo MTL, (2000). Antimicrobial and antioxidant activities of Feijoa sellowiana fruit. International Journal of Antimicrobial Agents, 13, 197-201.

[14] Ruberto G and Tringali C, (2004). Secondary metabolites from the leaves of Feijoa sellowiana Berg. Phytochemistry, 65, 2947-2951.

[15] Weston RJ, (2010). Bioactive products from fruit of the feijoa (Feijoa sellowiana, Myrtaceae): a review. Food Chemistry, 121, 923-926.

[16] Mosbah H, Louati H, Boujbiha MA, Chahdoura H, Snoussi M, Flamini G, Ascrizzi R, Bouslema A, Achour L, Selmi B, (2018). Phytochemical characterization, antioxidant, antimicrobial and pharmacological activities of Feijoa sellowiana leaves growing in Tunisia. Industrial crop and products, 112, 521-531.

[17] Lapcik O, Klejdus B, Kokoska L, Davodoava M, Afandi K, Kuban V and Hampl R, (2005). Identification of isoflavones in Acca sellowiana and two Psidium species (Myrtaceae). Biochemical Systematics and Ecology, 33, 983-992.

[18] Poodi Y, Bimakr M, Ganjloo A and Zarringhalami S, (2018). Intensification of bioactive compounds extraction from feijoa (Feijoa sellowiana Berg.) leaves using ultrasonic waves. Food and Bioproducts Processing, 108, 3750 .

[19] Aoyama H, Sakagami H, Hatano T, (2018). Three new flavonoids, proanthocyanidin, and accompanying phenolic constituents from Feijoa sellowiana. Bioscience Biotechnology and Biochemistry, 82, 31-41.

[20] Zhu F, (2018). Chemical and biological properties of feijoa (Acca sellowiana). Trends in Food Science and Technology, 81, 121-131.

\section{How to cite this article}

Aniq Filali O, Elfarnini M, Abdel-hamid AA and Blaghen M. (2019). Chemical composition of isoflavones compounds and antioxidants from Feijoa sellowiana leaves. GSC Biological and Pharmaceutical Sciences, 9(1), 120-124. 